\title{
Analysis of Available Vessels and Storage Capacities in Case of Large Oil Spill in European Union with Particular Reference to Republic of Croatia
}

\author{
Merica Slišković, Helena Ukić, Pero Vidan, Goran Jerković
}

Considering the constant growth of maritime transport and the role of the European Union in the international seaborne trade, it is important to determine the readiness of the EU in case of marine pollution. This paper summarizes the data regarding the number of the vessels ready for the response, and immediate and long-term storage facilities for the oily waste collected after an operation on the European Union territory. The aim of the study is to show the current available operational capacities in each Member State, as well as to determine the strength and capacity of five European regions for a prompt and efficient response to an oil spill. This paper seeks to highlight the importance of practical details that should be accessible and well prepared when an oil spill occurs. Based on the analysis of secondary data, it was found out that the Mediterranean area has the largest number of vessels ready for response in case of oil pollution, while the largest storage capacity for oily waste on shore is in the Baltic region. Particular reference is given to the Republic of Croatia which currently has nine available response vessels with the total storage capacity on board of $49.7 \mathrm{~m}^{3}$.

\section{KEY WORDS}

$\sim$ Marine pollution

$\sim$ Oil spill

$\sim$ Oil response vessels

$\sim$ Storage facilities

University of Split, Faculty of Maritime Studies, Split, Croatia

e-mail: hukic@pfst.hr

doi: 10.7225/toms.v06.n02.003

This work is licensed under (cc) BY

\section{INTRODUCTION}

The UN defines marine pollution as: "The introduction by man, directly, or indirectly, of substances or energy to the marine environment resulting in deleterious effects such as hazards to human health, hindrance to marine activities, impairment of the quality of seawater for various uses and reduction of amenities" (United Nations Convention on the Law of the Sea, 1982).

There are various sources of pollution such as sewage, sedimentation, solid waste, biological, chemicals, radioactive substances, oil, etc. One of the major pollutants worldwide besides sewage and solid waste is oil. Every year, millions of tons of oil end up in the marine environment which has devastating consequences on marine ecosystems. When an oil spill occurs, the influence which will affect the environment can be determined by the type and amount of toxic constituents which are present in a petroleum product (Stoyanov et al., 2017).

Oil spills can be caused by operational and accidental discharges during shipping activities. Most incidents of oil spills were the result of a combination of different actions and circumstances. Most of the oil spills are caused by tankers, and a recently increased amount of oil gets into the marine environment due to daily operations. Operational causes are classified as loading/unloading and other operations. Accidental causes often cause major spills of oil, and are classified as collision, grounding, fire or explosion. The residue discharge is caused by routine operations. Even though statistics show that the number of large oil spills has decreased, we should not neglect smaller spills which occur on daily basis, especially in the areas of increased traffic, such as China and some parts of the European coasts (e.g. Barents and North Seas) (Kirby and Law, 2010; Woolgar, 2008). 
As International Maritime Organization underlines, the response to marine pollution incidents requires special knowledge and expertise, as well as dedicated equipment and tools (International Maritime Organization, 2017). The key to each response to oil pollution is to reduce damage to the environment and socio-economic resources. Since the oil is identified as contaminant, the ultimate goal is to reduce the time for recovery from oil. The best way to achieve this is the process of Net Environmental Benefit Analysis. Important steps for the implementation of this process are collection of information on physical characteristics, ecology, checking previous spills and the methods that were used, predicting the consequences for the environment, and checking the advantages and disadvantages of different methods of cleaning the oil (IPIECA, Response Strategy Development Using Net Environmental Benefit Analysis (NEBA), 2015).

The subject of this paper is to analyze the capacity and equipment of the EU Member States in case of marine pollution by oil and to identify the location for the reception of oily wastes after cleaning and rehabilitation. The analysis was carried out by using the available sources of primary and secondary data: Inventory of EU member states' oil pollution response vessels in 2016, and Study on discharge facilities for oil recovered at sea in 2012 (Inventory of EU Member States Oil Pollution Response Vessels in 2016, 2016; Study on Discharge Facilities for Oil Recovered at Sea in 2012, 2012).

Upon analysis, the summary of the total capacity that EU has on disposal will be provided. As official EU statistics differentiate between five European sea areas (the Baltic Sea, North Sea, Black Sea, Atlantic, and Mediterranean regions), the overview of capacities including vessels, equipment, and on-shore-based capacities for the reception of waste will be analyzed through these regions. Results are provided for the European countries, EFTA countries, and candidate countries. The latest available data for the Republic of Croatia were collected, and the analysis of the current state of the vessels and equipment is given.

\section{AVAILABLE VESSELS, STORAGE CAPACITIES ON VESSELS AND OIL-DISCHARGING FACILITIES IN THE EUROPEAN UNION}

Oil spills at sea are unpredictable and interventions in major accidents require the involvement of several countries. The methods which will be used during oil spill incident in a specific area depend on the characteristics of the oil spill and the characteristics of the area where the spill occurred, such as climate, oceanographic or geographical features of the biological and economic potential. They also depend on the available equipment, logistic support and staff teamwork. The key points for an optimal response regarding waste generation after oil spills are the knowledge of the best available techniques and the awareness of logistical constraints.
When an oil spill occurs, the most important part is the quick and timely response, and the big problem may arise if the wrong mode of action is taken. For this reason, the majority of countries have made plans in case of accidental marine oil pollution, i.e. Contingency Plans, which represent a guide for the action in case of accidental pollution.

In case of an oil spill in the European seas, a network of 16 fully equipped stand-by ships for the response is established (European Maritime Safety Agency, 2017). The primary objective of the Stand-by Oil Spill Response Vessel service is to "top-up" the marine oil recovery capacity of Member States, thus minimizing the potential impact on the European coastline. The Stand-by Oil Spill Response Vessels will, under normal circumstances, carry out their usual commercial activities. However, in the event of an oil spill, and following a request for assistance from a Member State, the nominated vessel will cease its normal activities and, at short notice, be mobilized and operate as a certified oil recovery vessel (European Maritime Safety Agency, 2017).

Each response method, chemical or mechanical, brings a different kind of waste that should be temporary stored and disposed of in a long term. The efficient and rapid discharge of the at-sea recovered oil is essential in order to allow these specialized vessels to maximize their time spent in oil spill recovery operations (Study on Discharge Facilities for Oil Recovered at Sea in 2012, 2012).

Besides storages on shore, if the vessel has storage capacities on board ship, a better planning of complete logistics for the response operation is possible.

In addition to an established network of standby ships, systems for monitoring Clean Sea Net and MAR-ICE, and other preventive or operational measures for the prevention of pollution, it is of great importance to determine the capacity of individual states, private and governance mechanisms that are used in the response to a marine pollution.

According to the available data (Inventory of EU Member States Oil Pollution Response Vessels in 2016, 2016; Study on Discharge Facilities for Oil Recovered at Sea in 2012, 2012), in Tables 1 and 2, the overview of available vessels and equipment, on board storages, and possible facilities for discharge $\left(\mathrm{m}^{3}\right)$ on shore is presented.

It is also important to underline some facts about the methods of analyzing the secondary data which are presented in the tables. The comparison of two different studies is provided.

The Oil Spill Response Vessel Inventory for 2016 provides information on the pollution preparedness and response mechanisms and capabilities of the EU, EFTA coastal States and Turkey, long-time candidate for EU (Inventory of EU Member States Oil Pollution Response Vessels in 2016, 2016). The data given throughout this document include complete specifications and details about vessels, equipment, and anti-pollution equipment. All the vessels that are processed during the study are defined in the same way. For this comparison, we decided to 
extract data about the number of vessels for each country and their storage capacity on board. Within the table, the following abbreviations for the types of vessels will be used: Emergency Towing Vessel - ETV, Search and Rescue Boat - SAR, and Oil Recovery Vessels - ORV. Besides them, multipurpose vessels and other categories of ships are also included.

The second study, Discharge facilities for oil recovered at sea (2012), presents all the available on-shore facilities (immediate and long-term) for the reception of oil recovered at sea which is collected by the specialized oil spill response vessels. During this research, there were some restrictions that were taken into consideration. Each facility had to been suitable to accommodate EMSA's vessels and receive recovered oil, and the relative capacity had to be at least $1,000 \mathrm{~m}^{3}$. The total of 35 facilities (495 of them were contacted, 67 replied) were marked as suitable for this kind of operations (Study on Discharge Facilities for Oil Recovered at Sea in 2012, 2012). Therefore, the data that will be presented do not refer to the total state of possible storage capacity for the

Table 1.

Overview of available vessels, storage capacities on vessels and oil discharging facilities in European Union by country. Source: Made by authors according to data extracted from Oil Spill Response Inventory (2016) and Discharge facilities for oil recovered at sea (2012) (Inventory of EU Member States Oil Pollution Response Vessels in 2016, 2016; Study on Discharge Facilities for Oil Recovered at Sea in 2012, 2012).

\begin{tabular}{|c|c|c|c|c|}
\hline \multirow[t]{2}{*}{ Country } & \multirow{2}{*}{$\begin{array}{l}\text { No. of vessels } \\
\text { (ETV, ORV, SAR, } \\
\text { Multipurpose) }\end{array}$} & \multirow{2}{*}{$\begin{array}{l}\text { Total storage } \\
\text { capacity on vessels } \\
\left(\mathrm{m}^{3}\right)\end{array}$} & \multicolumn{2}{|c|}{ Potential oil discharging facilities (capacities in $\mathrm{m}^{3}$ ) } \\
\hline & & & Immediate & Long term \\
\hline Belgium & 7 & $\mathrm{n} / \mathrm{a}$ & $1,600.00$ & $1,000.00$ \\
\hline Bulgaria & 8 & 895.60 & $\mathrm{n} / \mathrm{a}$ & $\mathrm{n} / \mathrm{a}$ \\
\hline Croatia & 21 & $\mathrm{n} / \mathrm{a}$ & $\mathrm{n} / \mathrm{a}$ & $\mathrm{n} / \mathrm{a}$ \\
\hline Cyprus & 3 & $\mathrm{n} / \mathrm{a}$ & $2,000.00$ & $2,500.00$ \\
\hline Denmark & 10 & $1,672.20$ & $7,000.00$ & $25,000.00$ \\
\hline Estonia & 4 & 459.00 & $\mathrm{n} / \mathrm{a}$ & $\mathrm{n} / \mathrm{a}$ \\
\hline Finland & 18 & $5,898.10$ & $17,900.00$ & $20,800.00$ \\
\hline France & 9 & $1,971.50$ & $3,000.00$ & $8,500.00$ \\
\hline Germany & 30 & $15,565.00$ & $1,000.00$ & $3,000.00$ \\
\hline Greece & 10 & 290.00 & $9,500.00$ & $44,500.00$ \\
\hline Iceland & 1 & 640.00 & $\mathrm{n} / \mathrm{a}$ & $\mathrm{n} / \mathrm{a}$ \\
\hline Ireland & 1 & $\mathrm{n} / \mathrm{a}$ & $57,000.00$ & $57,000.00$ \\
\hline Italy & 39 & $4,435.06$ & $7,950.00$ & $37,000.00$ \\
\hline Latvia & 6 & 286.00 & $10,000.00$ & $20,000.00$ \\
\hline Lithuania & 3 & 353.00 & $7,000.00$ & $5,000.00$ \\
\hline Malta & 9 & 264.20 & $3,500.00$ & $6,500.00$ \\
\hline Norway & 23 & $8,376.20$ & $\mathrm{n} / \mathrm{a}$ & $\mathrm{n} / \mathrm{a}$ \\
\hline Poland & 10 & 844.00 & $\mathrm{n} / \mathrm{a}$ & $\mathrm{n} / \mathrm{a}$ \\
\hline Portugal & 22 & 360.70 & $27,500.00$ & $45,000.00$ \\
\hline Romania & 18 & 230.00 & $2,500.00$ & $5,000.00$ \\
\hline Slovenia & 3 & $\mathrm{n} / \mathrm{a}$ & $\mathrm{n} / \mathrm{a}$ & $\mathrm{n} / \mathrm{a}$ \\
\hline Spain & 14 & $4,442.00$ & $10,400.00$ & $14,700.00$ \\
\hline Sweden & 15 & $6,478.00$ & $131,000.00$ & $143,000.00$ \\
\hline Turkey & $\mathrm{n} / \mathrm{a}$ & $\mathrm{n} / \mathrm{a}$ & $60,000.00$ & $60,000.00$ \\
\hline Netherlands & 19 & $48,991.00$ & $10,000.00$ & $25,000.00$ \\
\hline United Kingdom & $\mathrm{n} / \mathrm{a}$ & $\mathrm{n} / \mathrm{a}$ & $2,000.00$ & $1,600.00$ \\
\hline
\end{tabular}


Table 2.

Available vessel storage capacities and oil discharging facilities in European Union by areas.

Source: Made by authors according to data extracted from Oil Spill Response Inventory (2016) and Discharge facilities for oil recovered at sea (2012) (Inventory of EU Member States Oil Pollution Response Vessels in 2016, 2016; Study on Discharge Facilities for Oil Recovered at Sea in 2012, 2012).

\begin{tabular}{|c|c|c|c|c|}
\hline Area & Country & No. of vessels & $\begin{array}{l}\text { Total storage capacity on } \\
\text { vessel }\left(\mathrm{m}^{3}\right)\end{array}$ & $\begin{array}{l}\text { Potential oil discharging } \\
\text { facilities (capacities in } \mathrm{m}^{3} \text { ) }\end{array}$ \\
\hline \multirow{8}{*}{ Baltic Sea } & Denmark & 10 & $1,672.20$ & $32,000.00$ \\
\hline & Estonia & 4 & 459.00 & 0.00 \\
\hline & Finland & 18 & $5,898.10$ & $38,700.00$ \\
\hline & Latvia & 6 & 286.00 & $30,000.00$ \\
\hline & Lithuania & 3 & 353.00 & $12,000.00$ \\
\hline & Poland & 10 & 844.00 & 0.00 \\
\hline & Sweden & 15 & $6,478.00$ & $274,000.00$ \\
\hline & Total & 66 & $15,990.30$ & $386,700.00$ \\
\hline \multirow{7}{*}{ North Sea } & Belgium & 7 & 0.00 & $2,600.00$ \\
\hline & Germany & 30 & $15,565.00$ & $4,000.00$ \\
\hline & Iceland & 1 & 640.00 & 0.00 \\
\hline & Norway & 23 & $8,376.20$ & 0.00 \\
\hline & The Netherlands & 19 & $48,991.00$ & $35,000.00$ \\
\hline & UK & 0 & 0.00 & $36,000.00$ \\
\hline & Total & 80 & $73,572.20$ & $77,600.00$ \\
\hline \multirow{3}{*}{ Atlantic Region } & Ireland & 1 & 0.00 & $114,000.00$ \\
\hline & Portugal & 22 & 360.70 & $72,500.00$ \\
\hline & Total & 23 & 360.70 & $186,500.00$ \\
\hline \multirow{10}{*}{ Mediterranean Sea } & Croatia & 21 & 0.00 & 0.00 \\
\hline & Cyprus & 3 & 0.00 & $4,500.00$ \\
\hline & France & 9 & $1,971.50$ & $11,500.00$ \\
\hline & Greece & 10 & 290.00 & $54,000.00$ \\
\hline & Italy & 39 & $4,435.06$ & $44,950.00$ \\
\hline & Malta & 9 & 264.20 & $10,000.00$ \\
\hline & Slovenia & 3 & 0.00 & 0.00 \\
\hline & Spain & 14 & $4,442.00$ & $25,100.00$ \\
\hline & Turkey & 0 & 0.00 & $120,000.00$ \\
\hline & Total & 108 & $11,402.76$ & $270,050.00$ \\
\hline \multirow{3}{*}{ Black Sea } & Bulgaria & 8 & 895.60 & 0.00 \\
\hline & Romania & 18 & 230.00 & $7,500.00$ \\
\hline & Total & 26 & $1,125.60$ & $7,500.00$ \\
\hline
\end{tabular}


reception of oily waste across the European seas. For the purpose of this paper, only the data regarding possible location of storage facility and capacity in $\mathrm{m}^{3}$ will be shown.

According to Table 1, Italy and Germany are the countries with the highest number of vessels for response to oil pollution. There are 39 vessels in Italy and all of them had class ORV, which is not the case with other countries. For example, Germany is in the second place according to the number of vessels, but as a difference from Italy has 18 oil response vessels, and also has an emergency towing vessel, and ice breakers. Regarding the storage capacity on board, it should be noted that the Netherlands has a significant fleet with the largest storage capacity on ships, with the total of $48,991.00 \mathrm{~m}^{3}$. For some of the countries, such as Turkey or Ireland, there are no available data regarding storages on board, but e.g. they have available huge storage capacities on shore (immediate and long-term). Turkey ranks second and Ireland ranks third regarding storage facilities on shore.

Sweden has the largest storage capacity on shore, $131,000.00 \mathrm{~m}^{3}$ for immediate storage, and 143,000.00 $\mathrm{m}^{3}$ for long term storage of oily waste.

Although it appears that the Republic of Croatia is within the top five countries in terms of the number of vessels, it is important to note that 10 of them are ORV and 11 of them are SAR.

Except for the capacity analysis per country, it is essential to link a particular country to the European seas to which it belongs and thus to determine the strength and ability of each of the European regions for a prompt and proper response to a potential oil spill.

Table 2 analyzes vessels, their capacity, and total storage capacities available on shore through regions. Some of the EU Member States border more than one sea, but in the comparison one country will be taken into consideration only once. The criterion for the selection was the area of the country which has access or is bordering a particular sea. If the area is greater for a specific region, then the state was affiliated to this region or sea, e.g. in the case of Spain, which can be related to the Atlantic and Mediterranean regions, where the significance of the Mediterranean region is greater.

According to the data, $90 \%$ of the European Union's external freight and $40 \%$ of its internal freight is carried by sea (Transport, Connecting Europe's Citizens and Businesses, 2014), and the busiest routes are those in the Baltic and Mediterranean regions.

As indicated in Table 2, in case of large oil spills countries in the Mediterranean Sea have 108 vessels at their disposal, available for response with the total capacity of $11,402.76 \mathrm{~m}^{3}$ on board vessels, and $270,050.00 \mathrm{~m}^{3}$ for storage of oily waste on shore. It can be noted that the Mediterranean region has the largest number of vessels which can be deployed, but after the oil recovery operation the largest on-shore storage capacities for oily waste acceptance are in the Baltic region, with the total of $386,700.00$ $\mathrm{m}^{3}$. The Baltic Sea countries have so far successfully responded to any pollution which was recorded in their waters, and HELCOM had a very important role. The ships that sail the Baltic Sea must adhere to strict regional and global regulations on the prevention of discharges of oil (HELCOM, 2017).

The North Sea data should also be highlighted. This area is one of the most potential threats due to the majority of offshore operations. The table shows that the North Sea area has the largest storage capacity on vessels $\left(73,572.20 \mathrm{~m}^{3}\right)$ which is almost 7 times higher than the Mediterranean region.

For the European part of the Black Sea (Bulgaria and Romania), there are 26 vessels on disposal and a small storage capacity on vessels and on shore, approximately $8,500.00 \mathrm{~m}^{3}$ in total.

If there is a potential threat, the above mentioned data could easily lead to a wrong conclusion about the equipment and preparedness of the EU countries for a fast and effective response in case of pollution.

Already in 2013 the European Economic and Social Committee (EESC), through their Opinion about multiannual funding for the action of the European Maritime Safety Agency in the field of response to pollution caused by ships and to marine pollution caused by oil and gas installations (Proposal for a Regulation of the European Parliament and of the Council, 2013), stated that the network of 19 stands by oil response vessels (at this moment there are 16 vessels on disposal) might be insufficient for the entire EU coastal area, and also raised the question whether the Member States and neighboring countries were sufficiently equipped to respond to a larger scale pollution. Similarly, the Committee warned that the planned funds for enhanced oil equipment in the period 2014 - 2020 may become sub-optimal and that an improvement of equipment for offshore spills, additional dispersant capabilities and replacement of oil response pollution equipment was needed (Proposal for Regulation of the European Parliament and of the Council, 2013).

Besides the equipment improvement, the member states should discuss the optimal distribution of storage facilities (short term and long term) on the mainland, and their redevelopment for the acceptance of EMSA's vessels. A lack of storage facilities for oily waste and their remoteness translates into additional costs and could delay a prompt and effective response.

\section{AVAILABLE VESSELS AND STORAGE CAPACITIES ON BOARD IN REPUBLIC OF CROATIA}

Although the Adriatic Sea is relatively small and well preserved, it is highly threatened by the extensive growth of maritime traffic and dangerous cargo in particular, of which crude oil traffic is the most dangerous (Lušić et al., 2008). The main cargo seaports like Trieste, Venice, Koper, and Rijeka are situated in the 
northern Adriatic and they are associated in the North Adriatic Ports Association - NAPA. Every year more than 100 million tons of cargo are handled in NAPA seaports, which is not surprising considering the perfect position of seaports which make the most appropriate gateway to the main European markets (Twrdy and Batista, 2014). The main advantage of NAPA seaports is 2,000 $\mathrm{Nm}$ shorter naval route from the Far East via Suez to Europe in comparison with other North-European ports (North Adriatic Port Association, 2017).

The constant annual growth of traffic in NAPA seaports is expected; recent data show $3.3 \%$ increase in the total cargo handled in 2016 compared to 2015 (North Adriatic Port Association, 2017).

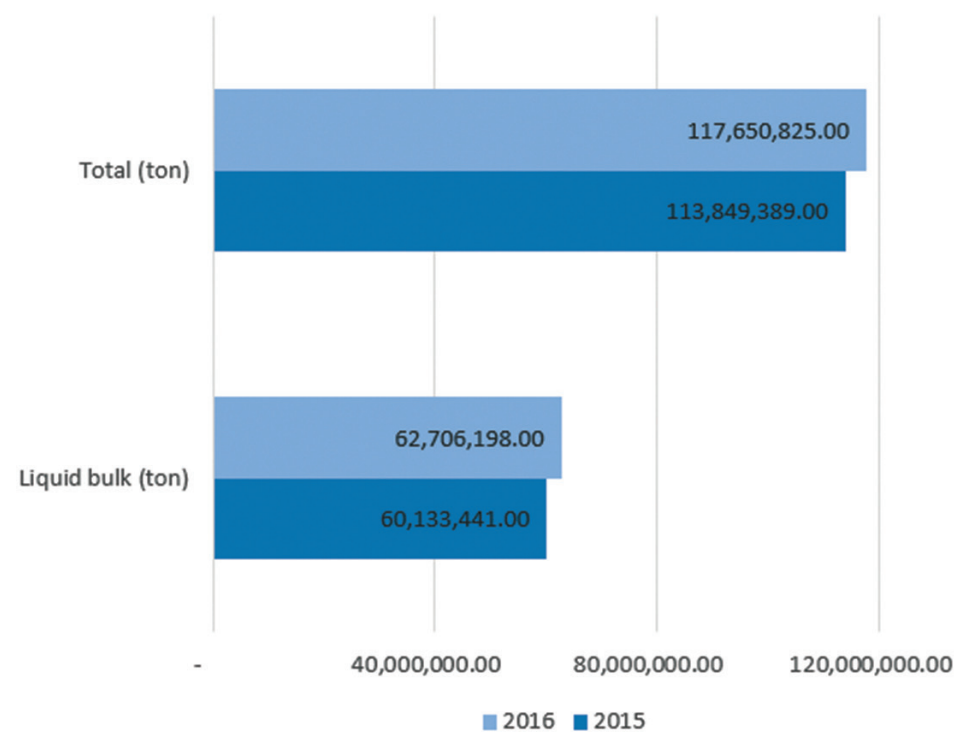

Figure 1.

Overview of total cargo and liquid bulk handled in NAPA seaports for 2015 and 2016.

Source: Made by authors using data of North Adriatic Ports Association (NAPA) (North Adriatic Port Association, 2017).

According to the Figure 1, comparing 2015 and 2016, except the increase in total cargo handled, the increase of liquid bulk is also recorded in NAPA seaports. It is evident that the majority of the total cargo handled in these ports (approximately $50 \%$ ) is liquid bulk. Also, the new transportation route for the Caspian oil, and One Belt One Road initiative will foster the growth of not only NAPA seaports, but the eastern Adriatic ports as well.

The presented facts and figures indicate an increased risk of potential pollution of the Adriatic, wherein the greatest threat is certainly oil pollution. From the foregoing, the importance of the prevention activities and response planning should be emphasized. There are six countries that have access to the Adriatic Sea, three of which are EU member countries, and the other three countries are candidates or potential candidates. Each country has its own contingency plans for response to pollution, but in case of a major pollution Croatia, Slovenia and Italy have the Sub-regional Contingency Plan for the prevention of, preparedness for and response to major marine pollution incidents that shall be activated.
The first step in the protection is an identification of the subject and equipment which are capable of intervention in the case of marine pollution. If there is an oil spill, and the Contingency plan is activated, the identified equipment must be available and the response teams must be trained to handle the equipment correctly. During the inventory of equipment by EMSA, the relative data for Croatia were not complete. There were no detailed data on the amount of storage capacity, operation of the vessel and pollution equipment on board the vessel.

Although Table 1 indicates that the Republic of Croatia had 21 available vessels along the coast in 2016, the analysis of the relative data reveals that only 10 of them were oil response vessels of which one was in the past for a few months indicated as "not available" due to the technical limitations (Nacrt Zaključka o prihvaćanju Godišnjeg programa rada Županijskog operativnog centra za provedbu Plana intervencija kod iznenadnih onečišćenja mora u Dubrovačko- neretvanskoj županiji za 2017. godinu, 2017). According to the available data of the Ministry of Sea, Transport and Infrastructure of the Republic of Croatia, besides the above mentioned ORV vessels there are two ETV 
Table 3.

Overview of available oil recovery vessels and appropriate equipment in case of oil spill.

Source: Made by authors according to the data provided by the Ministry of Sea, Transport and Infrastructure of the Republic of Croatia (2017) (Zaštita Jadrana, Ministry of Sea, Transport and Infrastructure of Republic of Croatia, 2017).

\begin{tabular}{|c|c|c|c|c|}
\hline Category & Vessel Name & $\begin{array}{l}\text { Place of storage } \\
\text { (longitude and } \\
\text { latitude) }\end{array}$ & $\begin{array}{l}\text { Purpose and technical specification of equipment on } \\
\text { board vessel }\end{array}$ & $\begin{array}{l}\text { Storage } \\
\text { capacity } \\
\left(\mathrm{m}^{3}\right)\end{array}$ \\
\hline ORV & INKOCLEAN EKO C1 & $\begin{array}{l}\text { Split, Croatia } \\
(43.506 \text { N } 16.441 \mathrm{E})\end{array}$ & $\begin{array}{l}\text { Specialized vessel for collecting hydrocarbons and } \\
\text { solid waste from the sea surface. Equipment: portable } \\
\text { submersible turbine pump for collection of oily water, } \\
\text { dispersants, brush skimmer, hydraulic platforms for the } \\
\text { collection of floating waste. }\end{array}$ & $\mathrm{n} / \mathrm{a}$ \\
\hline ORV & ECO $13 / 5$ & $\begin{array}{l}\text { Split, Croatia } \\
(43.506 \text { N } 16.438 \text { E) }\end{array}$ & Equipment: brush skimmer, dispersants, booms & 4.8 \\
\hline ORV & ECOI & $\begin{array}{l}\text { Pula, Croatia } \\
(44.871 \text { N } 13.839 \mathrm{E})\end{array}$ & $\begin{array}{l}\text { Collection of solid and liquid waste from the sea } \\
\text { surface, encircling contamination by protective curtains, } \\
\text { application of dispersants, aeration undersea }\end{array}$ & 10 \\
\hline ORV & ECO II & $\begin{array}{l}\text { Rijeka, Croatia } \\
(45.323 \text { N } 14.444 \mathrm{E})\end{array}$ & $\begin{array}{l}\text { Collection of solid and liquid waste from the sea } \\
\text { surface, encircling contamination by protective curtains, } \\
\text { application of dispersants, aeration undersea }\end{array}$ & 10 \\
\hline ORV & ECO III & $\begin{array}{l}\text { Rijeka, Croatia } \\
(45.322 \mathrm{~N} 14.437 \mathrm{E})\end{array}$ & $\begin{array}{l}\text { Collection of solid and liquid waste from the sea } \\
\text { surface, encircling contamination by protective curtains, } \\
\text { application of dispersants, aeration undersea }\end{array}$ & 10 \\
\hline ORV & ECO 13/4 & $\begin{array}{l}\text { Rijeka, Croatia } \\
(45.321 \mathrm{~N} 14.448 \mathrm{E})\end{array}$ & $\begin{array}{l}\text { Collection of solid and liquid waste from the sea } \\
\text { surface, encircling contamination by protective curtains. } \\
\text { Equipment: Foilex micro skimmer, firefighting pump, } \\
\text { pump for dispersant application, crane }\end{array}$ & 5 \\
\hline ORV & ECO $13 / 3$ & $\begin{array}{l}\text { Zadar, Croatia } \\
(44.119 \text { N } 15.226 \mathrm{E})\end{array}$ & $\begin{array}{l}\text { Emergency response vessel (transportation of the } \\
\text { equipment), collection of solid and liquid waste from } \\
\text { the sea surface, encircling contamination by protective } \\
\text { curtains. Equipment: skimmers, booms, dispersants and } \\
\text { two cranes. }\end{array}$ & 4.6 \\
\hline ORV & ECO $13 / 2$ & $\begin{array}{l}\text { Šibenik, Croatia } \\
\text { (43.737 N 15.884 E) }\end{array}$ & $\begin{array}{l}\text { Equipment: booms, dispersants, skimmer, firefighting } \\
\text { equipement, crane }\end{array}$ & 0.3 \\
\hline ORV & ECO 13/1 & 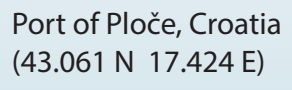 & $\begin{array}{l}\text { Not on disposal from March } 2017 \text { due to technical and } \\
\text { mechanical deficiencies. }\end{array}$ & $\mathrm{n} / \mathrm{a}$ \\
\hline ORV & INKOCLEAN EKO C2 & $\begin{array}{l}\text { Dubrovnik, Croatia } \\
(42.644 \text { N } 18.095 \mathrm{E})\end{array}$ & $\begin{array}{l}\text { Specialized vessel for collecting hydrocarbons and solid } \\
\text { waste from the sea surface. Equipment: brush skimmer, } \\
\text { front crane basket for collection of floating waste, } \\
\text { dispersants (dispersant capacity } 1000 \text { l) , booms }\end{array}$ & 5 \\
\hline
\end{tabular}

vessels (storage capacities not available), three barges $(6,200$ $\mathrm{m}^{3}$ total storage capacity) and one tanker for the transport and manipulation of oil and other fluids $\left(1,054 \mathrm{~m}^{3}\right.$ storage capacity on board).
Table 3 gives the summarized data of the available storage capacities and equipment on board each response vessel. Also, where the data was available the purpose of the ships is indicated. 
Regarding the distribution of the vessels, they are well positioned and the Primorsko-Goranska County, where the main cargo port Rijeka is located, has the largest number of vessels and available equipment. A possible problem may arise in the port of Ploče, Croatia's second biggest cargo port, where from this year there are no available response vessels. For planning effective response, the information about available storage capacity on response vessels is also important. From the data above, it is evident that some of the ORV vessels have very low capacities. The total available capacities for these available 10 ships is 49.7 $\mathrm{m}^{3}$.

Due to the uneven data, we were not able to properly display the available storage facilities on shore.

\section{CONCLUSIONS/RECOMMENDATIONS}

For the purpose of effective and timely response, and in terms of available equipment and storage capacity, the following recommendations should be followed:

- Regular and, if applicable, annual update of information about available vessels and equipment for pollution response.

- Review the information on storage capacities on the mainland, and invite all Member States (the competent authorities) to collect and maintain the unified database of possible storage capacities.

- Accurate and updated data will help identification of provision of additional equipment, ships and storage capacities, and thus enable the adoption of support measures for an increase of storage capacities as well as initialization of sustainable management for collected oily waste.

- Plan the location of equipment and storage capacities according to the estimated risk.

- The Republic of Croatia should improve the database of active equipment and storage capacities through legislative measures or with the help of EU funds encourage the purchase of additional equipment for the response.

\section{REFERENCES}

Brusendorff, A. C., Korpinen, S., Meski, L. and Stankiewicz, M., (2012), HELCOM Actions to Eliminate Illegal and Accidental Oil Pollution from Ships in the Baltic Sea, in: Kostianoy, A. and Lavrova, O. (eds), Oil Pollution in the Baltic Sea, The Handbook of Environmental Chemistry, 27, Berlin, Heidelber: Springer. https://doi.org/10.1007/698_2011_131

European Maritime Safety Agency, (2017), official web page, available at: http:// www.emsa.europa.eu/, [accessed 10 February 2017.].

HELCOM, (2017), Baltic Marine Environment Protection Commission - Helsinki Commission, official web page, available at: http://www.helcom.fi/, [accessed 11 June 2017.].

International Maritime Organization, (2017), official web page, available at: http://www.imo.org/en/OurWork/Environment/PollutionResponse/ OilPollutionResources/Pages/Default.aspx, [accessed 18 September 2017.].
Inventory of EU Member States Oil Pollution Response Vessels in 2016, (2016), European Maritime Safety Agency, available at: http://www.emsa.europa.eu/ news-a-press-centre/external-news/item/2777-inventory-of-eu-member-states-oilpollution-response-vessels-2016.html, [accessed 10 February 2017.].

IPIECA, Response Strategy Development Using Net Environmental Benefit Analysis (NEBA), (2015), IOGP Report 527, available at: http://www.oilspillresponseproject. org/wp-content/uploads/2016/02/GPG-Net-Environmental-Benefit-Analysis.pdf, [accessed 10 April 2017.].

Kirby, M. F. and Law, J. R., (2010), Accidental Spills at Sea - Risk, Impact, Mitigation and the Need for Co-ordinated Post-incident Monitoring, Marine Pollution Bulletin, 60(6), pp. 797-803.,

https://doi.org/10.1016/j.marpolbul.2010.03.015

Lušić, Z, Erceg, T. and Baljak, K., (2008), The Main Adriatic Ports and Their Traffic, Proc. 2nd International Maritime Scientific Conference, Lumbarda, Croatia, June 17 - 21, pp. 185-199.

Nacrt Zaključka o prihvaćanju Godišnjeg programa rada Županijskog operativnog centra za provedbu Plana intervencija kod iznenadnih onečišćenja mora u Dubrovačko- neretvanskoj županiji za 2017. godinu, (2017), available at: http:// www.edubrovnik.org/wp-content/uploads/2017/03/7.-Program-rada-\%C5\%BDOCone\%C4\%8Di\%C5\%A1\%C4\%87enje-mora.pdf, [accessed 15 June 2017.].

North Adriatic Port Association (NAPA), (2017), official web page, available at: http:// www.portsofnapa.com/, [accessed 15 June 2017.].

Proposal for a Regulation of the European Parliament and of the Council, (2013), Procedure 2013/0092/COD, Brussels: EU Commission, available at: http://eur-lex. europa.eu/eli/reg/2014/911/oj, [accessed 15 June 2017.].

Study on Discharge Facilities for Oil Recovered at Sea in 2012, (2012), European Maritime Safety Agency, Environmental Protection Engineering SA, Technical report, Contract Number 11/EMSA/OP/O7/2011, available at: http://www.emsa. europa.eu/about/download/2048/1665/23.html, [accessed 14 February 2017.].

Stoyanov, S., Kozarev, N. and Ilieva, N., (2017), Water Pollution and Waste Management in Port Areas, University of Chemical Technology and Metallurgy, available at: http://www.pse.ice.bas.bg/www_systems_engineerig_laboratory/ Distance_learning_systmeng/Distance_Course_5/Distance_Course_5_EN/ Lecture_Course_5_EN/Lekcii_Course_5_PDF_EN/Lecture_13_ENG.pdf, [accessed 15 July 2017.].

Transport, Connecting Europe's Citizens and Businesses, (2014), Brussels, Belgium: European Commission, Directorate - General for Communication Citizens Information, available at: http://europa.eu/pol/index_en.htm, [accessed 10 June 2017.].,

https://doi.org/10.2775/13082

Twrdy, E. and Batista, M., (2014), Port Competition in North Adriatic, Naše more, $61(3-4)$, pp. $47-51$

United Nations Convention on the Law of the Sea - Part I, Article 1, (1982), available at: http://www.un.org/depts/los/convention_agreements/texts/unclos/part1.htm, [accessed 15 July 2017.].

Woolgar, L., (2008), Assessing the Increasing Risk of Marine Oil Pollution Spills in China, International Oil Spill Conference, Savannah, GA, USA, May 4 - 8, 2008, pp. 711-715.,

https://doi.org/10.7901/2169-3358-2008-1-711

Zaštita Jadrana, Ministry of Sea, Transport and Infrastructure of Republic of Croatia, (2017), available at: http://www.mppi.hr/default.aspx?id=476, [accessed 10 June 2017.]. 